\title{
Radiation Hazard Assessment by Measuring of Soil Radioactivity Levels in Al-anbar (Al-fallujah District) and Wasit Governorate in Iraq
}

\author{
Takrid Muneam Nafae, Haydar Ahmed Hasan, Abbas Neamah Mohammed, Alaa Fadhil Hashim
}

Radiation and Nuclear Safety Directorate (RNSD), Ministry of Science and Technology, Baghdad, Iraq

Email address:

taghreed_nafea@yahoo.com(T.M. Nafae),alnajjar_1964@yahoo.com(H. A. Hasan), abbasneamah@gmail.com(A.N.Mohammed)

\section{To cite this article:}

Takrid Muneam Nafae, Haydar Ahmed Hasan, Abbas Neamah Mohammed, Alaa Fadhil Hashim. Radiation Hazard Assessment by Measuring of Soil Radioactivity Levels in Al-anbar (Al-fallujah District) and Wasit Governorate in Iraq. International Journal of High Energy Physics. Vol. 5, No. 1, 2018, pp. 5-11. doi: 10.11648/j.ijhep.20180501.12

Received: October 27, 2017; Accepted: November 11, 2017; Published: January 5, 2018

\begin{abstract}
Soil samples were collected from two region Al-anbar (Al-fallujah district) and Wasit of Iraq with an aim to determine the activity concentration using a coaxial high purity germanium (HPGe) detector based on high-resolution gamma spectrometry system. ${ }^{226} \mathrm{Ra},{ }^{232} \mathrm{Th}$, the primordial radionuclide ${ }^{40} \mathrm{~K}$, and the artificial radionuclide ${ }^{137} \mathrm{Cs}$ were measured in the soil of the study area. The mean radioactivity concentration in Al-anbar (Al-fallujah district) and Wasit region due to ${ }^{226} \mathrm{Ra},{ }^{232} \mathrm{Th}$, ${ }^{40} \mathrm{~K}$, and ${ }^{137} \mathrm{Cs}$ was $\left(20.36,11.08,226.97\right.$, and $\left.1.01 \mathrm{~Bq} \mathrm{~kg}{ }^{-1}\right)$ and $\left(23.01,14.45,290.64\right.$, and $\left.2.22 \mathrm{~Bq} \mathrm{~kg}^{-1}\right)$, respectively. Radium equivalent activity $\left(\mathrm{Ra}_{\mathrm{eq}}\right)$, representative level index $\left(\mathrm{I}_{\gamma}\right)$, absorbed gamma dose rate (D) in air, total annual effective dose equivalent (AEDE) from the terrestrial gamma radiation, the external and internal hazard index were estimated. The mean of six hazard index values came out to be $\left(53.67 \mathrm{~Bq} \mathrm{~kg}^{-1}, 0.38 \mathrm{~Bq} \mathrm{~kg}^{-1}, 24.78 \mathrm{~Bq} \mathrm{~kg}^{-1}, 0.15 \mathrm{mSv} \mathrm{y} \mathrm{y}^{-1}, 0.14 \mathrm{~Bq} \mathrm{~kg}^{-1}\right.$, and $0.19 \mathrm{~Bq} \mathrm{~kg}$ ) in $\mathrm{Al}-$ anbar (Al-fallujah district) and $\left(66.17 \mathrm{~Bq} \mathrm{~kg}^{-1}, 0.49 \mathrm{~Bq} \mathrm{~kg}^{-1}, 32.08 \mathrm{~Bq} \mathrm{~kg}^{-1}, 0.2 \mathrm{mSv} \mathrm{y}^{-1}, 0.18 \mathrm{~Bq} \mathrm{~kg}^{-1}\right.$, and $_{0.24} \mathrm{~Bq} \mathrm{~kg}^{-1}$ ) in Wasit, respectively. Present data have been compared with the published data for other regions of the world near from the study area and found to be safe for public and environment.
\end{abstract}

Keywords: Radiation Hazard, Annual Effective Dose, Gamma Spectrometry

\section{Introduction}

Human beings have always been exposed to natural radiations arising from within and outside the earth. The primordial radionuclides have radioactive decay half-lives that are approximately earth's age. The exposure to ionizing radiations from natural sources occurs because of the naturally occurring radioactive elements in the soil and rocks, cosmic rays entering the earth's atmosphere from outer space and the internal exposure through incorporation of these radionuclides into the body by inhalation or ingestion. These radionuclides and their radioactive decay products are an important source of earth's radioactivity $[1,2]$. The natural radioactivity in soil primarily comes from ${ }^{238} \mathrm{U}$ and ${ }^{232} \mathrm{Th}$ series and natural ${ }^{40} \mathrm{~K}$. Artificial radionuclides can also be present such a ${ }^{137} \mathrm{Cs}$, resulting from fallout from weapons testing and from accidents such as Chernobyl. The radiological implication of these radionuclides is due to the gamma ray exposure of the body and irradiation of lung tissue from inhalation of radon and its daughters. The great number of decay products of ${ }^{238} \mathrm{U}$ and ${ }^{232} \mathrm{Th}$ series and ${ }^{40} \mathrm{~K}$ are the main components of external gamma radiation originating from soil. Therefore, the assessment of gamma radiation dose from natural sources is of particular importance as natural radiation is the largest contributor to the external dose of the world population [1]. The average annual radiation dose to world population is $2.8 \mathrm{mSv}$ approximately $85 \%(2.4 \mathrm{mSv})$ of this comes from natural radionuclides of both terrestrial and cosmogenic origin [3]. ${ }^{137} \mathrm{Cs}$ is regarded as the most important constituent of worldwide radioactive fallout. Sixty percent of the collective effective dose equivalent commitment from external radiation associated with past atmospheric 
nuclear weapon testing may be attributed to ${ }^{137} \mathrm{Cs}$. In the case of an accidental release of fission products from a nuclear power plant, cesium isotopes are especially significant due to their volatility and large inventory that builds up in the reactor over time. Therefore, measurement of ${ }^{137} \mathrm{Cs}$ levels in soil is necessary in the environment of a studied area as such a data would serve as the baseline data. Its presence in soil would be an indicator that the area under study might have received some fallout radioactivity in the past [4]. The specific levels are related to the types of rock from which the soils originate. Higher radiation levels are associated with igneous rocks, such as granite, and lower levels with sedimentary rocks [1]. The present study deals with the measurement of specific activities of ${ }^{226} \mathrm{Ra},{ }^{232} \mathrm{Th},{ }^{40} \mathrm{~K}$ and ${ }^{137} \mathrm{Cs}$, calculation of the radium equivalent activity, external and internal hazard indices, absorbed dose and annual effective dose equivalent for the studied area. This data will help to decide whether the studied region is in an area of normal or high background radiation and will set a baseline for the determination of radioactivity level in the region [4].

\section{Materials and Methods}

\subsection{Description of Study Area}

Soil sampling was carried out in 2011. The geological locate of the two governorate Al-anbar (Al-fallujah district) and Wasit at west and middle of Iraq. Soil samples were collected from three selected sites at Al-anbar (Al-fallujah district) governorate and six selected sites at Wasit governorate, which were chosen for two reasons: first record rise in cancers and birth defects rates in the surrounding residential areas of sites according to the information that has been obtained from hospital near the sites or from the governorate council and the second that these areas have seen some of them military operations were reconstruction and other division is the remnants of the wreckage of vehicles and wheels military destroyer and some rubble of buildings. The description of the study area has been reported elsewhere in reference [5]. Tables $1 \& 2$ were shown the description of the study area at Al-anbar (Al-fallujah district) and Wasit governorate respectively while Figure 1 was shown the soil sampling locations on map of Al-anbar (Al-fallujah district) and Wasit governorate respectively.

Table 1. The description of the study area at Al-anbar (Al-fallujah district) governorate.

\begin{tabular}{lllll}
\hline Sample No. & Sample ID & Location description & Latitude & Longitude \\
\hline 1 & B.G.S1 & Golan background (its far $1000 \mathrm{~m}$ from Golan selected area). & 33.36684 & 43.76478 \\
2 & S1-1 & Golan district near the railroad tracks (rubble, with height $2 \mathrm{~m}$ and area $\left.(400 \times 1000) \mathrm{m}^{2}\right)$. & 33.36830 & 43.75455 \\
3 & S1-2 & Golan district-residential neighborhood (rubble, with height $2 \mathrm{~m}$ and area $\left.(250 \times 400) \mathrm{m}^{2}\right)$. & 33.35956 & 43.75394 \\
4 & S1-3 & Golan district-rivers edge (rubble, with height $2 \mathrm{~m}$ and area $\left.(4 \times 100) \mathrm{m}^{2}\right)$. & 33.35384 & 43.7591 \\
5 & B.G.S2 & Al-shuhada district background (its far $1000 \mathrm{~m}$ from Al-shuhada selected area). & 33.33219 & 43.80234 \\
6 & S2-1 & Al-shuhada district-residential region (rubble, with height $2 \mathrm{~m}$ and area $\left.(250 \times 600) \mathrm{m}^{2}\right)$. & 33.32848 & 43.79225 \\
7 & S2-2 & Al-shuhada district-land region (rubble, with height $2 \mathrm{~m}$ and area $\left.(20 \times 25) \mathrm{m}^{2}\right)$. & 33.33928 & 43.79327 \\
8 & B.G.S3 & Jubail district background (its far $1000 \mathrm{~m}$ from Jubail selected area). & 33.33281 & 43.77237 \\
9 & S3-1 & Jubail district-dam way (rubble, with height $1 \mathrm{~m}$ and area $\left.(25 \times 50) \mathrm{m}^{2}\right)$. & 33.32701 & 43.78090 \\
10 & S3-2 & Jubail district-Fliah Revir area (residential district). & 33.33965 & 43.77910 \\
11 & S3-3 & Jubail district. & 33.34213 & 43.76955 \\
\hline
\end{tabular}

Table 2. The description of the study area at Wasit governorate.

\begin{tabular}{|c|c|c|c|c|}
\hline Sample No. & Sample ID & Location description & Latitude & Longitude \\
\hline 1 & B.G.S1 & Governorate office background (its far $1000 \mathrm{~m}$ from selected area). & 32.51353 & 45.81960 \\
\hline 2 & S1 & $\begin{array}{l}\text { Governorate council office (This site is subjected to a military strike, which has been } \\
\text { reconstruction, and there are some debris and soil is left in strike place). }\end{array}$ & 32.50436 & 45.82496 \\
\hline 3 & B.G.S2 & Alsharqiya Alkhajah region background (its far $1000 \mathrm{~m}$ from selected area). & 32.52886 & 45.78931 \\
\hline 4 & S2 & Alsharqiya Alkhajah region (residual wreckage of military vehicle). & 32.52956 & 45.80229 \\
\hline 5 & B.G.S3 & Taba healthy center background (its far $1000 \mathrm{~m}$ from selected area). & 32.51252 & 45.81259 \\
\hline 6 & S3 & Taba healthy center. & 32.50632 & 45.81761 \\
\hline 7 & B.G.S4 & Shield factory background (its far $1000 \mathrm{~m}$ from selected area). & 32.91072 & 45.06351 \\
\hline 8 & S4 & $\begin{array}{l}\text { Shield factory in Alaziziya region (surface radiological survey / rubble, with height } 1 \mathrm{~m} \text { and } \\
\text { area } 400 \mathrm{~m}^{2} \text {. }\end{array}$ & 32.90719 & 45.07164 \\
\hline 9 & B.G.S5 & Saad abn maath school background (its far $1000 \mathrm{~m}$ from selected area) & 32.90509 & 45.05841 \\
\hline 10 & S5 & $\begin{array}{l}\text { Saad abn maath school in Alaziziya region (surface radiological survey for land of school } \\
\text { which used as military replacement site }\end{array}$ & 32.91008 & 45.05025 \\
\hline
\end{tabular}




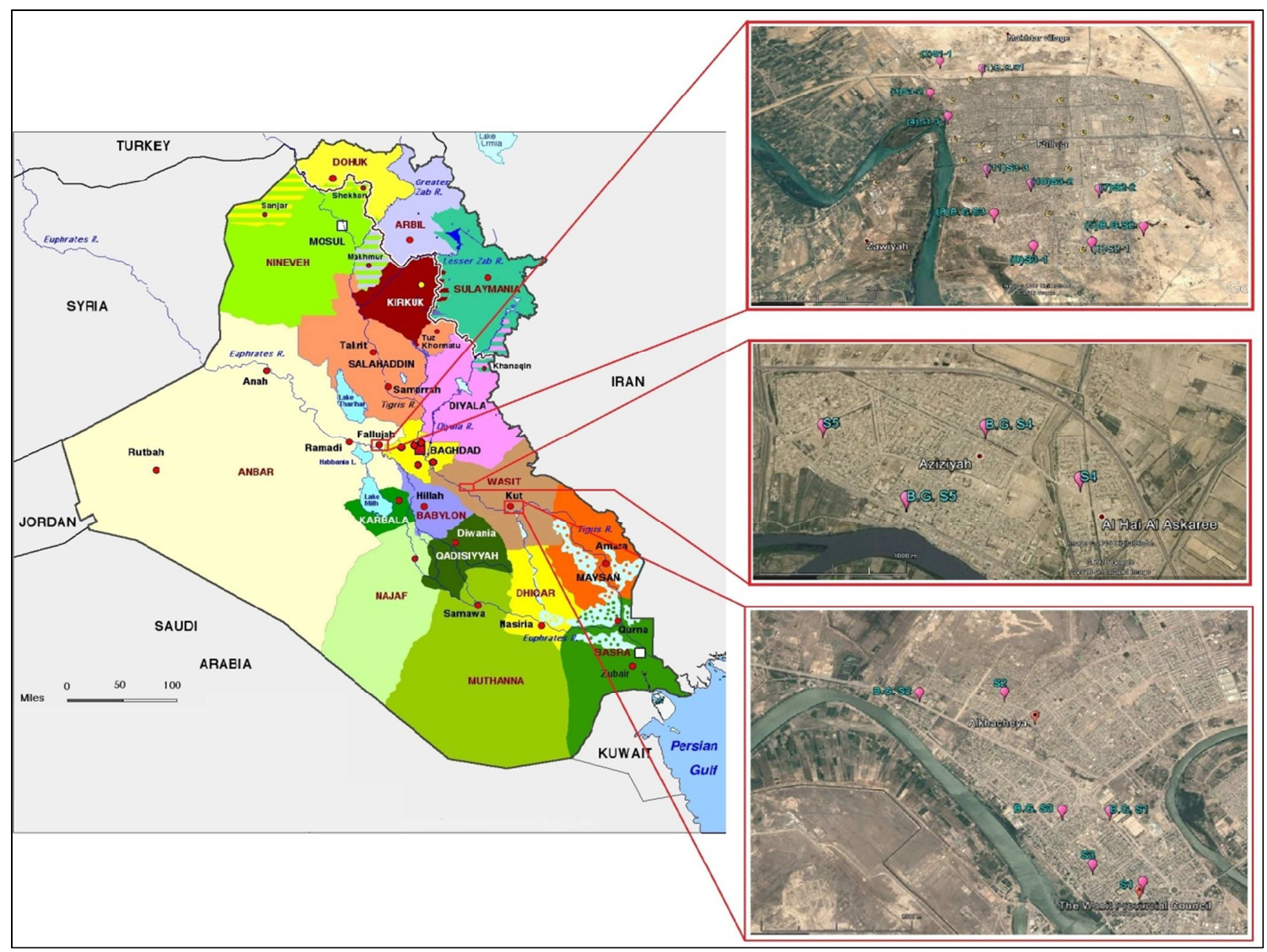

Figure 1. Sampling location map in Al-anbar (Al-fallujah district) and Wasit governorate.

\subsection{Sample Preparation}

At each site, samples were taken from layer down to $25 \mathrm{~cm}$ depth. Fine quality of the sample was obtained using sieve of 9 mesh size ( $2 \mathrm{~mm}$ particle size). An average $0.5 \mathrm{~kg}$ of soil was used per sample. Before measurement samples were dried in an oven at a temperature of $80^{\circ} \mathrm{C}$ for $8 \mathrm{hr}$. These samples were packed and sealed in a marinelli beaker and kept for about 3 week period to allow radioactive equilibrium among the daughter products of radon, thoron and their short lived decay products [6].

\subsection{Sample Analysis}

The samples were analyzed at MOST Gamma Ray Spectrometry laboratory. Using high- resolution gamma spectrometry system consists of coaxial High Purity Germanium (HPGe) detector. The detector has resolution of $2.0 \mathrm{keV}$ and relative efficiency of $40 \%$ for $1.33 \mathrm{MeV}$ gamma energy of Co-60. The detector was shield with lead of thickness $10 \mathrm{~cm}$ and internally lined with $3 \mathrm{~mm}$ copper to reduce the environmental gamma background radiation. The efficiency calibration of the system was employed by reference materials. The gamma ray spectrum was recorded using software GENIE-2000. ${ }^{226} \mathrm{Ra}$ was assessed through the photo peaks of its daughters: ${ }^{214} \mathrm{~Pb}(352 \mathrm{keV})$ and ${ }^{214} \mathrm{Bi}$ $(609 \mathrm{keV})$ furthermore the concentration of ${ }^{232} \mathrm{Th}$ was determined through the photo peaks of ${ }^{228} \mathrm{Ac}(911 \mathrm{keV})$ and ${ }^{212} \mathrm{~Pb}(238.6 \mathrm{keV}) .{ }^{40} \mathrm{~K}$ and ${ }^{137} \mathrm{Cs}$ were measured directly from their 1460.8, $662 \mathrm{keV}$ gamma ray peaks [5].

\subsection{Radiation Hazard Indices}

\subsubsection{Radium Equivalent Activity}

To represent their specific activities levels of ${ }^{226} \mathrm{Ra},{ }^{232} \mathrm{Th}$, and ${ }^{40} \mathrm{~K}$ by a single quantity which take into calculation the radiation hazards related with them, a common radiological index has been used which is radium equivalent $\left(\mathrm{Ra}_{\mathrm{eq}}\right)$. To define $\mathrm{Ra}_{\mathrm{eq}}$ activity, it can be assumed that $1 \mathrm{~Bq} / \mathrm{kg}$ of ${ }^{226} \mathrm{Ra}$, $0.7 \mathrm{~Bq} / \mathrm{kg}$ of ${ }^{232} \mathrm{Th}$ or $13 \mathrm{~Bq} / \mathrm{kg}$ of ${ }^{40} \mathrm{~K}$ give the same dose of gamma ray.

The mathematically defined by Eq. (1) [4 \& 7]

$$
R a_{e q}=C_{R a}+1.43 C_{T h}+0.077 C_{K} \leq 370
$$

Where $C_{R a}, C_{T h}$, and $C_{K}$ are the activity concentrations of ${ }^{226} \mathrm{Ra},{ }^{232} \mathrm{Th}$, and ${ }^{40} \mathrm{~K}$ in $\mathrm{Bq} / \mathrm{kg}$

\subsubsection{Representative Level Index $\left(I_{\gamma}\right)$}

The representative level index $\left(\mathrm{I}_{\gamma}\right)$ used for the calculation of gamma radiation associated with the natural radioactive materials in the soil. It is calculated using Eq. (2). The safety value for this index is $\leq 1[8 \& 9]$

$$
I_{\gamma}=\frac{C_{R a}}{150}+\frac{C_{T h}}{100}+\frac{C_{K}}{1500} \leq 1
$$




\subsubsection{Air Absorbed Radiation Dose Rate}

Adsorbed dose rate in air at a height of about 1 meter above the ground surface due to gamma radiations for uniform distribution of the naturally occurring radionuclides ${ }^{226} \mathrm{Ra},{ }^{232} \mathrm{Th}$ and ${ }^{40} \mathrm{~K}$ is calculated using Eq. (3). The conversion factor of $0.462 \mathrm{nGy} \mathrm{h}^{-1} / \mathrm{Bq} \mathrm{kg}^{-1}$ for ${ }^{226} \mathrm{Ra}, 0.621$ $\mathrm{nGy} \mathrm{h}^{-1} / \mathrm{Bq} \mathrm{kg}^{-1}$ for ${ }^{232} \mathrm{Th}, 0.0417 \mathrm{nGy} \mathrm{h}^{-1} / \mathrm{Bq} \mathrm{kg}^{-1}$ for ${ }^{40} \mathrm{~K}$, and $0.136 \mathrm{nGy} \mathrm{h}^{-1} / \mathrm{Bq} \mathrm{kg}^{-1}$ for ${ }^{137} \mathrm{Cs}$ equilibrium is assumed between ${ }^{226} \mathrm{Ra}$ and ${ }^{232} \mathrm{Th}$ series with all their daughter and the effect of ${ }^{90} \mathrm{Sr}$ and ${ }^{235} \mathrm{U}$ decay series can be neglected because of their small contribution to the whole dose from background. [4 \& 7]

$$
\begin{gathered}
D\left(\mathrm{nGy} \mathrm{h}^{-1}\right)=0.462 C_{R a}+0.621 C_{T h}+0.0417 C_{K}+ \\
0.136 C_{C s}
\end{gathered}
$$

\subsubsection{Annual Effective Dose Rate}

The annual effective dose rates expected to be received by the general public due to the radioactivity in soil was calculated using Eq. $(4 \& 5)$ the conversion coefficient from absorbed dose rate in air to effective dose $\left(0.7 \mathrm{~Sv} \mathrm{~Gy}^{-1}\right)$ and an outdoor occupancy factor $(20 \%)$ proposed by UNSCEAR 2000 are used $[1,4,7]$.

$$
\begin{aligned}
\operatorname{Indoor}(\mathrm{mSv} / \mathrm{y}) & =(\text { Absorbeddose }) n G y h^{-1} \times 8760 \mathrm{h.} \mathrm{yr}^{-1} \\
& \times 0.8 \times 0.7 \times\left(10^{3} \mathrm{mSv} / 10^{9} \mathrm{nGy}\right)
\end{aligned}
$$

Outdoor $(n S v / y)=($ Absorbeddose $) n G y h^{-1} \times 8760 h$

$$
\times 0.2 \times 0.7 \times\left(10^{3} \mathrm{mSv} / 10^{9} \mathrm{nGy}\right)
$$

\subsubsection{External and Internal Hazard Index [9 \& 10]}

The external hazard index $\left(\mathrm{H}_{\mathrm{ex}}\right)$ is widely used to reflect to external exposure and can be calculated by Eq. (6):

$$
H_{e x}=\frac{C_{R a}}{370}+\frac{C_{T h}}{259}+\frac{C_{K}}{4810}<1
$$

In addition to the external hazard index, radon and its short-lived products are also hazardous to the respiratory organs. The internal hazard indexes $\left(\mathrm{H}_{\mathrm{in}}\right)$ used to reflect to internal exposure to radon and its daughter, which is given by Eq. (7):

$$
H_{\text {in }}=\frac{C_{R a}}{185}+\frac{C_{T h}}{259}+\frac{C_{K}}{4810}<1
$$

The values of the indices of external and internal radiation hazard index must be less than unity for the radiation hazard to be negligible.

\section{Results and Discussion}

The data in Table ( $3 \& 4)$ are summarized of measurements of natural and manmade radionuclide $\left({ }^{226} \mathrm{Ra}\right.$, ${ }^{232} \mathrm{Th},{ }^{40} \mathrm{~K}$, and ${ }^{137} \mathrm{Cs}$ ) concentration and radium equivalent in the collected soil samples from Al-anbar (Al-fallujah district) and Wasit governorate, respectively. The mean activity concentration at Al-anbar (Al-fallujah district) due to ${ }^{226} \mathrm{Ra}$, ${ }^{232} \mathrm{Th},{ }^{40} \mathrm{~K}$, and ${ }^{137} \mathrm{Cs}$ was $20.36,11.08,226.84$, and $1.01 \mathrm{~Bq}$ $\mathrm{kg}^{-1}$, respectively. In Wasit governorate, the mean activity concentration due to ${ }^{226} \mathrm{Ra},{ }^{232} \mathrm{Th},{ }^{40} \mathrm{~K}$, and ${ }^{137} \mathrm{Cs}$ was 23.01 , 14.54, 290.64, and $2.22 \mathrm{~Bq}_{\mathrm{kg}}{ }^{-1}$, respectively. ${ }^{137} \mathrm{Cs}$ concentration was detected very low at most of the places. Its concentration at $\mathrm{Al}$-anbar (Al-fallujah district) governorate ranged from 0.00 to $2.3 \mathrm{~Bq} \mathrm{~kg}^{-1}$ with an average value of 1.01 $\mathrm{Bq} \mathrm{kg}{ }^{-1}$ and at Wasit governorate was ranged from 0.70 to $5.06 \mathrm{~Bq} \mathrm{~kg}^{-1}$ with an average value of $2.22 \mathrm{~Bq} \mathrm{~kg}^{-1}$ and these concentration survey low at most of the places for that they don't have any radiological important. The activity concentration of ${ }^{226} \mathrm{Ra},{ }^{232} \mathrm{Th}$, and ${ }^{40} \mathrm{~K}$ in soil samples of studied area was compared with the value reported by other countries near from study area as shown in Table (5). The measured activity concentration of ${ }^{226} \mathrm{Ra}$ and ${ }^{232} \mathrm{Th}$ was close to the Syria and Iran for Al-anbar (Al-fallujah district) and

\begin{tabular}{|c|c|c|c|c|c|}
\hline Sample ID & $\begin{array}{l}\text { A.Conc. of }{ }^{226} \mathrm{Ra} \\
\mathrm{Bq} / \mathrm{kg}\end{array}$ & $\begin{array}{l}\text { A.Conc. of }{ }^{232} \mathrm{Th} \\
\text { Bq/kg }\end{array}$ & $\begin{array}{l}\text { A.Conc. of }{ }^{40} K \\
\text { Bq/kg }\end{array}$ & $\begin{array}{l}\text { A.Conc. of } \\
{ }^{137} \mathrm{CsBq} / \mathrm{kg}\end{array}$ & $\mathrm{Ra}_{\mathrm{eq}}(\mathrm{Bq} / \mathrm{kg})$ \\
\hline B.G.S1 & 21.8 & 13.5 & 280.5 & 1.2 & 62.70 \\
\hline S1-1 & 17.4 & 5.6 & 137.02 & 0.85 & 35.96 \\
\hline S1-2 & 21.6 & 14.8 & 278.4 & 0 & 64.20 \\
\hline $\mathrm{S} 1-3$ & 22.5 & 15.2 & 271.6 & 0.5 & 65.15 \\
\hline B.G.S2 & 21.3 & 13.02 & 306 & 1.9 & 63.48 \\
\hline S2-1 & 19.8 & 6.9 & 134.2 & 0.32 & 40.00 \\
\hline $\mathrm{S} 2-3$ & 27.7 & 19 & 371 & 0 & 83.44 \\
\hline B.G.S3 & 14.4 & 9.6 & 247 & 0.3 & 47.15 \\
\hline S3-1 & 23.2 & 4.6 & 113.8 & 1.18 & 38.54 \\
\hline S3-2 & 14.7 & 9.5 & 177.4 & 2.3 & 41.94 \\
\hline S3-3 & 20.5 & 9.4 & 172 & 1.9 & 47.19 \\
\hline Mean value & 20.36 & 11.08 & 226.89 & 1.01 & 53.67 \\
\hline Min value & 14.40 & 4.60 & 113.80 & 0.00 & 35.96 \\
\hline
\end{tabular}
Wasit. While the measured activity concentration of ${ }^{40} \mathrm{~K}$ was closed to Southern Jordan and Syria for two governorates. Furthermore, the world average concentrations for ${ }^{226} \mathrm{Ra}$, ${ }^{232} \mathrm{Th}$, and ${ }^{40} \mathrm{~K}$ in soil sample are $35,30,400 \mathrm{~Bq} / \mathrm{kg}$, respectively [7].

Table 3. Activity concentrations of ${ }^{226} \mathrm{Ra},{ }^{232} \mathrm{Th},{ }^{40} \mathrm{~K}$, and ${ }^{137} \mathrm{Cs}$ and radium equivalent activity in soil samples from Al-anbar (Al-fallujah district) governorate. 
Table 4. Activity concentration of ${ }^{226} \mathrm{Ra},{ }^{232} \mathrm{Th},{ }^{40} \mathrm{~K}$, and ${ }^{137} \mathrm{Cs}$ and radium equivalent activity in soil samples from Wasit governorate.

\begin{tabular}{|c|c|c|c|c|c|}
\hline Sample ID & $\begin{array}{l}\text { A.Conc. of }{ }^{226} \mathrm{Ra} \\
\mathrm{Bq} / \mathrm{kg}\end{array}$ & $\begin{array}{l}\text { A.Conc. of }{ }^{232} \mathrm{Th} \\
\mathrm{Bq} / \mathrm{kg}\end{array}$ & $\begin{array}{l}\text { A.Conc. of }{ }^{40} \mathrm{~K} \\
\mathrm{~Bq} / \mathrm{kg}\end{array}$ & $\begin{array}{l}\text { A.Conc. of } \\
{ }^{137} \mathrm{CsBg} / \mathrm{kg}\end{array}$ & $\mathrm{Ra}_{\mathrm{eq}}(\mathrm{Bq} / \mathrm{kg})$ \\
\hline B.G.S1 & 28.8 & 16.9 & 351.1 & 2.7 & 80.00 \\
\hline S1 & 19.5 & 13.3 & 303.7 & 2.4 & 61.90 \\
\hline B.G.S2 & 20.5 & 12.3 & 240.2 & 0.9 & 56.58 \\
\hline S2 & 17.2 & 10.7 & 203.2 & 2.4 & 48.15 \\
\hline B.G.S3 & 34.7 & 24.3 & 344.6 & 5.06 & 95.98 \\
\hline S3 & 25.5 & 17.7 & 442.1 & 4.4 & 84.85 \\
\hline B.G.S4 & 23.05 & 16.9 & 299.05 & 0.9 & 70.24 \\
\hline S4 & 15.7 & 7.78 & 172.2 & 1.45 & 40.08 \\
\hline B.G.S5 & 21.6 & 13 & 315.1 & 1.3 & 64.45 \\
\hline S5 & 23.5 & 12.5 & 235.1 & 0.7 & 59.48 \\
\hline Mean value & 23.01 & 14.54 & 290.64 & 2.22 & 66.17 \\
\hline Min value & 15.70 & 7.78 & 172.20 & 0.70 & 40.08 \\
\hline Max value & 34.70 & 24.30 & 442.10 & 5.06 & 95.98 \\
\hline Worldwide background soil standard & $10-50$ & $10-50$ & $100-700$ & & $\leq 370$ \\
\hline
\end{tabular}

Table 5. Activity concentration $\left(B q \mathrm{~kg}^{-1}\right)$ of natural radionuclides reported by various countries.

\begin{tabular}{|c|c|c|c|c|}
\hline Country & ${ }^{226} \mathrm{Ra}$ & ${ }^{232} \mathrm{Th}$ & ${ }^{40} \mathbf{K}$ & reference \\
\hline Syria & $19(6-69)$ & $24(3-50)$ & $336(85-735)$ & 10 \\
\hline Southern Jordan & 42.5 & 26.7 & 291.1 & 2 \\
\hline Turkey & 79 & 62 & 574 & 4 \\
\hline Istanbul & 27.7 & 32.5 & 388 & 10 \\
\hline Iran & 28 & 22 & 640 & 1 \\
\hline World average & 35 & 30 & 400 & 7 \\
\hline Present study Al-anbar (Al-fallujah district) governorate & 20.36 & 11.08 & 226.89 & 5 \\
\hline Present study Wasit governorate & 23.01 & 14.54 & 290.64 & 5 \\
\hline
\end{tabular}

Radium equivalent activity $\left(\mathrm{Ra}_{\mathrm{eq}}\right)$ in $\mathrm{Bqkg}^{-1}$ for these soil samples were shown in Table 3 and 4. The mean radium equivalent activity in Al-anbar (Al-fallujah district) is 53.67 and in Wasit is $66.17 \mathrm{~Bq} \mathrm{~kg}^{-1}$ which is less than the safe limit $\left(370 \mathrm{~Bq} \mathrm{~kg}^{-1}\right.$ ) recommended by Organization for Economic Cooperation and Development [7].

Tables (6) and (7) were shown the five radiation hazard indices for soil samples for Al-anbar (Al-fallujah district) and Wasit governorate, respectively. The values of representative level index (I $\gamma)$ of soil samples ranged from 0.26 to $0.48 \mathrm{~Bq}$ $\mathrm{kg}^{-1}$ with a mean value of $0.38 \mathrm{~Bq} \mathrm{~kg}^{-1}$ for Al-anbar (Alfallujah district)governorate and ranged from 0.3 to $0.7 \mathrm{~Bq}$ $\mathrm{kg}^{-1}$ with a mean value of $0.49 \mathrm{~Bq} \mathrm{~kg}^{-1}$ for Wasit governorate. All values were lower the unity permissible limit. Equations $(3,4$, and 5$)$ were used to calculate the absorbed dose rate $D\left(\mathrm{nGy} \mathrm{h}^{-1}\right)$ and the effective dose rate $(m S v / y)$ in outdoor and indoor air for Al-anbar (Al-fallujah district) and Wasit governorate, as shown in Tables (6) and (7) respectively. The values of the total absorbed dose rate ranged from 17.35 to $31.23 \mathrm{nGy} \mathrm{h}^{-1}$ with a mean value of $24.78 \mathrm{nGy} \mathrm{h}^{-1}$ for $\mathrm{Al}-$ anbar (Al-fallujah district) governorate and ranged from 19.46 to $46.18 \mathrm{nGy} \mathrm{h}^{-1}$ with a mean value of $32.08 \mathrm{nGy} \mathrm{h}^{-1}$ for Wasit governorate. All values are lower than the world average value of $60 \mathrm{nGy} \mathrm{h}^{-1}$ given by UNCEAR 2000 [7]. All calculated values of the effective dose rate for two governorates are far lower than the $1.0 \mathrm{mSv}^{-1}{ }^{-1}$ recommended by UNSCEAR 2000. Furthermore the calculated values are near from the values which were calculated in the previous study [9] using ReCLAIM program version 3.0 as shown in Figures (2 and 3 ) for Al-anbar (Al-fallujah district) and Wasit governorate, respectively.

Table 6. The value of calculated radiation indices of soil samples for Al-anbar (Al-fallujah district) governorate.

\begin{tabular}{|c|c|c|c|c|c|c|c|}
\hline Sample ID & $\mathbf{I}_{\gamma}$ & $\begin{array}{l}\text { D } \\
n G y h^{-1}\end{array}$ & $\begin{array}{l}D_{\text {out }} \\
\text { mSv.y }^{-1}\end{array}$ & $\begin{array}{l}D_{\text {in }} \\
\text { mSv. }^{-1}\end{array}$ & $\begin{array}{l}\text { D }_{\text {totall }} \\
\text { mSv. }^{-1}\end{array}$ & $\mathbf{H}_{\mathrm{ex}}$ & $\mathbf{H}_{\text {in }}$ \\
\hline B.G.S1 & 0.47 & 30.32 & 0.04 & 0.15 & 0.19 & 0.17 & 0.23 \\
\hline S1-1 & 0.26 & 17.35 & 0.02 & 0.09 & 0.11 & 0.10 & 0.14 \\
\hline S1-2 & 0.48 & 30.78 & 0.04 & 0.15 & 0.19 & 0.17 & 0.23 \\
\hline $\mathrm{S} 1-3$ & 0.48 & 31.23 & 0.04 & 0.15 & 0.19 & 0.18 & 0.24 \\
\hline B.G.S2 & 0.48 & 30.94 & 0.04 & 0.15 & 0.19 & 0.17 & 0.23 \\
\hline S2-1 & 0.29 & 19.07 & 0.02 & 0.09 & 0.12 & 0.11 & 0.16 \\
\hline S2-3 & 0.62 & 40.07 & 0.05 & 0.2 & 0.25 & 0.23 & 0.3 \\
\hline B.G.S3 & 0.36 & 22.96 & 0.03 & 0.11 & 0.14 & 0.13 & 0.17 \\
\hline S3-1 & 0.28 & 18.48 & 0.02 & 0.09 & 0.11 & 0.10 & 0.17 \\
\hline S3-2 & 0.31 & 20.40 & 0.03 & 0.10 & 0.13 & 0.11 & 0.15 \\
\hline $\mathrm{S} 3-3$ & 0.35 & 22.74 & 0.03 & 0.11 & 0.14 & 0.13 & 0.18 \\
\hline Mean field soil value & 0.38 & 24.78 & 0.03 & 0.13 & 0.15 & 0.14 & 0.19 \\
\hline Min & 0.26 & 17.35 & 0.02 & 0.09 & 0.11 & 0.10 & 0.14 \\
\hline Max & 0.48 & 31.23 & 0.05 & 0.20 & 0.19 & 0.18 & 0.24 \\
\hline
\end{tabular}


Table 7. The value of calculated radiation indices of soil samples for Wasit governorate.

\begin{tabular}{|c|c|c|c|c|c|c|c|}
\hline Sample ID & $\left(\mathbf{I}_{\gamma}\right)$ & $\begin{array}{l}\text { D } \\
n G y h^{-1}\end{array}$ & $\begin{array}{l}D_{\text {out }} \\
\text { mSv. }^{-1}\end{array}$ & $\begin{array}{l}D_{\text {in }} \\
\text { mSv. }^{-1}\end{array}$ & $\begin{array}{l}\text { D }_{\text {totall }} \\
\text { mSv. }^{-1}\end{array}$ & Hex & Hin \\
\hline B.G.S1 & 0.60 & 38.81 & 0.05 & 0.19 & 0.24 & 0.22 & 0.29 \\
\hline $\mathrm{S} 1$ & 0.47 & 30.26 & 0.04 & 0.15 & 0.19 & 0.17 & 0.22 \\
\hline B.G.S2 & 0.42 & 27.25 & 0.03 & 0.13 & 0.17 & 0.15 & 0.21 \\
\hline $\mathrm{S} 2$ & 0.36 & 23.39 & 0.03 & 0.11 & 0.14 & 0.13 & 0.18 \\
\hline B.G.S3 & 0.70 & 46.18 & 0.06 & 0.23 & 0.28 & 0.26 & 0.35 \\
\hline $\mathrm{S} 3$ & 0.64 & 41.81 & 0.05 & 0.21 & 0.26 & 0.23 & 0.30 \\
\hline B.G.S4 & 0.52 & 33.74 & 0.04 & 0.17 & 0.21 & 0.19 & 0.25 \\
\hline S4 & 0.30 & 19.46 & 0.02 & 0.10 & 0.12 & 0.11 & 0.15 \\
\hline B.G.S5 & 0.48 & 31.37 & 0.04 & 0.15 & 0.19 & 0.17 & 0.23 \\
\hline S5 & 0.44 & 28.52 & 0.03 & 0.14 & 0.17 & 0.16 & 0.22 \\
\hline Mean field soil value & 0.49 & 32.08 & 0.04 & 0.16 & 0.20 & 0.18 & 0.24 \\
\hline Min & 0.30 & 19.46 & 0.02 & 0.10 & 0.12 & 0.11 & 0.15 \\
\hline Max & 0.70 & 46.18 & 0.06 & 0.23 & 0.28 & 0.26 & 0.35 \\
\hline
\end{tabular}

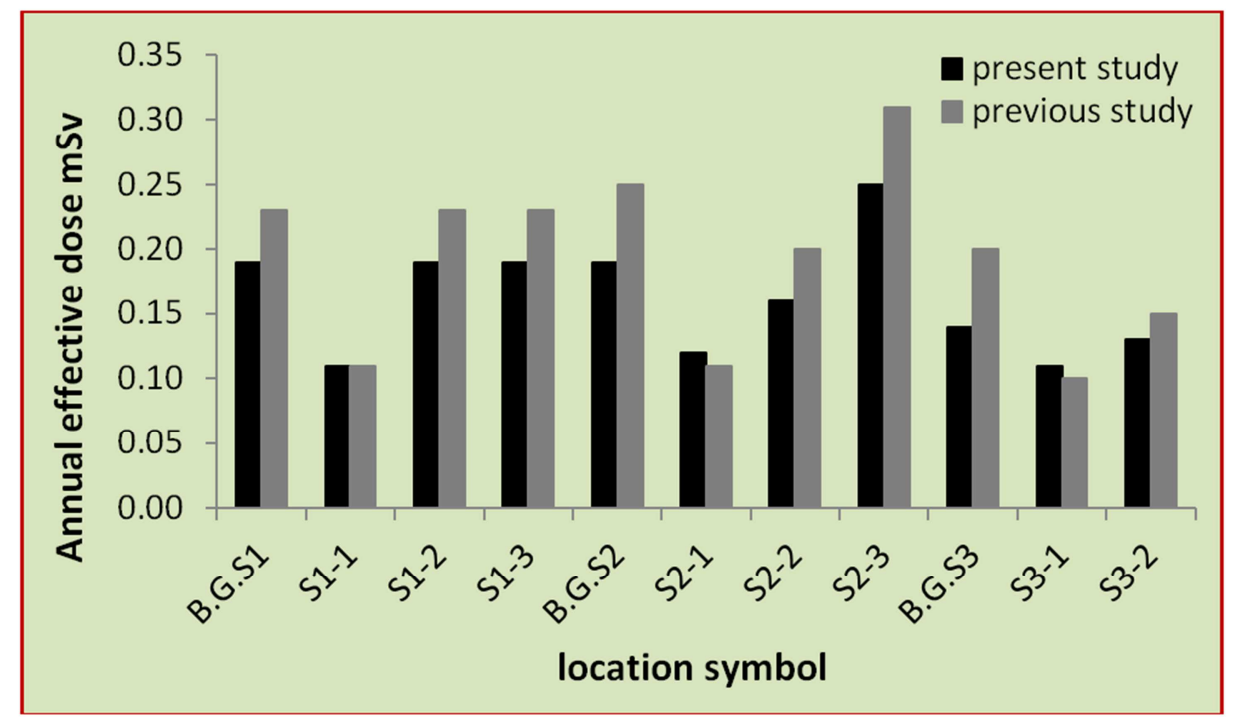

Figure 2. The annual effective dose comparison for Al-anbar (Al-fallujah district) governorate.

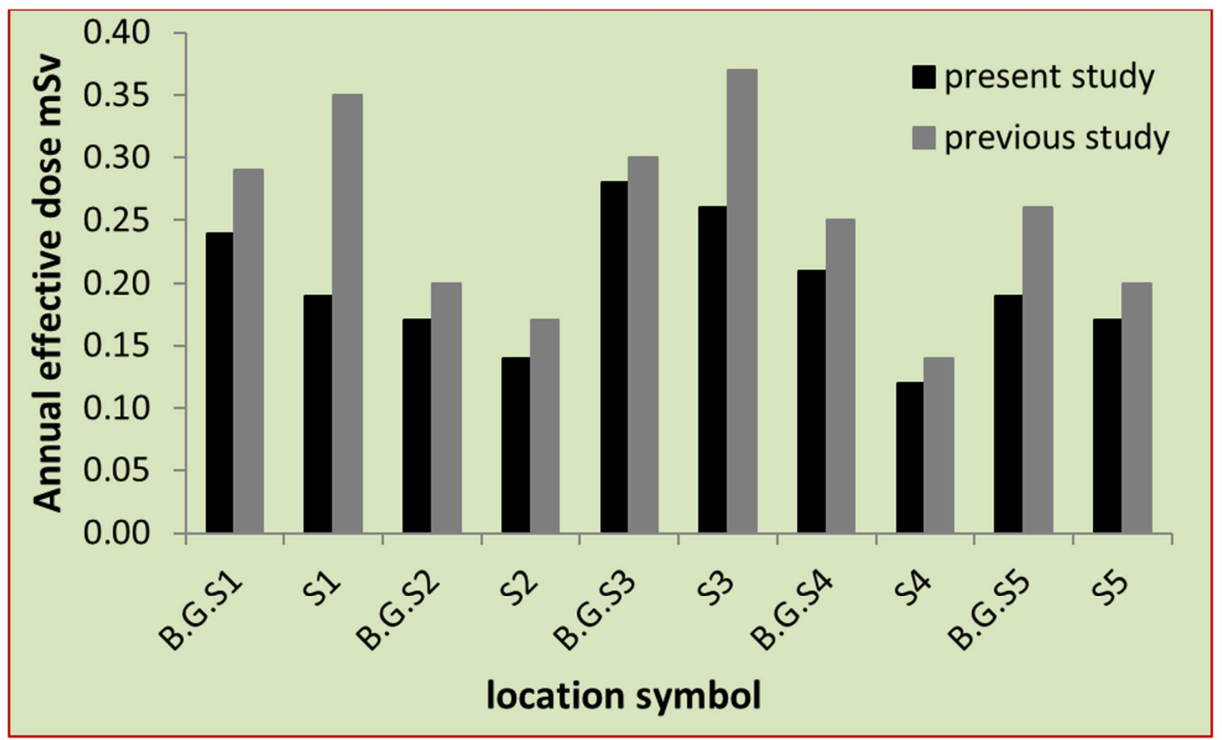

Figure 3. The annual effective dose comparison for Wasit governorate.

\section{Conclusions}

1. The measured activity concentration of ${ }^{226} \mathrm{Ra}$ and ${ }^{232} \mathrm{Th}$ was close to the Syria and Iran for Al-anbar (Al-fallujah district) and Wasit while the measured activity concentration of ${ }^{40} \mathrm{~K}$ was closed to Southern Jordan and 
Syria for two governorates. Furthermore, the world average concentrations for ${ }^{226} \mathrm{Ra},{ }^{232} \mathrm{Th}$, and ${ }^{40} \mathrm{~K}$ in soil sample are $35,30,400 \mathrm{~Bq} / \mathrm{kg}$ respectively.

2. ${ }^{137} \mathrm{Cs}$ concentration was detected very low at most of the places. Its concentration at Al-anbar (Al-fallujah district) governorate ranged from 0.00 to $2.3 \mathrm{~Bq} \mathrm{~kg}$ with an average value of $1.01 \mathrm{~Bq} \mathrm{~kg}^{-1}$ and at Wasit governorate was ranged from 0.70 to $5.06 \mathrm{~Bq} \mathrm{~kg}^{-1}$ with an average value of $2.22 \mathrm{~Bq} \mathrm{~kg}$ and these concentration survey low at most of the places for that they don't have any radiological important

3. The results obtained have shown that the effective dose rate values due to natural radioactivity of soil samples are far lower than the average world recommended value of $1.0 \mathrm{mSv}^{-1} \mathrm{y}^{-1}$ and near from the values were calculated using ReCLAIM program version 3.0.

\section{References}

[1] Rohit M., Surinder S., Kulwant S., Rajendra S., 2007. " ${ }^{226}$ Ra, ${ }^{232} \mathrm{Th}$ and ${ }^{40} \mathrm{~K}$ analysis in soil samples from some areas of Malwaresion, Punjab, India using gamma ray spectrometry". Environ Monit Asses. V 134, P 333-342.

[2] Jabbar A., Arshed W., Bhatti A. S., Ahmad S. S., Akhter P., Ur-Rehman S., Anjum M. I., 2010. "Measurement of soil radioactivity levels and radiation hazard assessment in southern Rechna interfluvial region, Pakistan". Environ Monit Asses. V 169, P 429-438.

[3] Bara S. V., Vishal Arora, Chinnaesakki S., Sartandel S. J., Bajwa B. S., Tripathi R. M., Puranik V. D., 2012.
"Radiological assessment of natural and fallout radioactivity in the soil of Chamba and Dharamshala areas of Himachal Pradesh, India". J Radioanal Nucl Chem., V 291, P. 769-776.

[4] Rahman S. U., Matiullah, Malik F., Rafique M., Anwar J., Ziafat M., Jabbar A., 2011. "Measurement of naturally occurring/fallout radioactive elements and assessment of annual effective dose in soil samples collected from four districts of the Punjab Province, Pakistan". J. Radioanal Nucl. Chem., V 287, P 647-655.

[5] Haydar Ahmed Hasan, Zeki Abduljabbar Mansoor, Omar Murbit, Hadi Mohammed Gabr, Takrid Muneam Nafae, 2011. "Evaluation of the Radioactivity of Selected Regions in Wasit and Anbar Governorates", journal of College of Science City University, V 3, N2, P 6-18.

[6] A GUIDEBOOK IAEA, 1989. "Measurement of Radionuclides in Food and The Environment".

[7] UNSCEAR [2000]. Sources and Effects of Ionizing Radiation. United Nations Scientific Committee on the effect of atomic radiation. New York: United Nations.

[8] Agbalagba E. O., Avwiri G. O., Chad-Umoreh Y. E., 2012. "ГSpectroscopy measurement of natural radioactivity and assessment of radiation hazard indices in soil samples from oil fields environment of Delta State, Nigeria". Journal of Environmental Radioactivity, V 109, P 64-70.

[9] Oyeyemi K. D. and Aizebeokhai A. P., 2015. "Geogenic Radiological Impact Assessment of Soil Samples Collected from Parts of Sagamu Southwestern Nigeria". Indian Journal Of Natural Sciences, V 6, N 33, P 10299 - 10308.

[10] Ebaid Y. Y., 2010. "Use of Gamma-Ray spectrometry for uranium isotopic analysis in environmental samples" Rom. Journ. Phys., V 55, Nos. 1-2, P. 69-74, Bucharest. 